\title{
On the local structure of $\mathrm{Ti}$ during in situ desorption of $\mathrm{Ti}(\mathrm{OBu})_{4}$ and $\mathrm{TiCl}_{3}$ doped $\mathrm{NaAlH}_{4}$
}

\author{
Cornelis P. Baldé ${ }^{\mathrm{a}}$, Ad M.J. van der Eerden ${ }^{\mathrm{a}}$, Hans A. Stil ${ }^{\mathrm{b}}$, Frank M.F. de Groot ${ }^{\mathrm{a}}$, \\ Krijn P. de Jong ${ }^{\text {a }}$, Johannes H. Bitter ${ }^{\mathrm{a}, *}$ \\ a Inorganic Chemistry and Catalysis, Department of Chemistry, Faculty of Sciences, \\ Universiteit Utrecht, Sorbonnelaan 16, 3584 CA Utrecht, The Netherlands \\ ${ }^{\mathrm{b}}$ Shell Research and Technology Centre, Badhuisweg 3, 1031 CM, Amsterdam, The Netherlands
}

Received 12 September 2006; received in revised form 28 November 2006; accepted 1 December 2006

Available online 29 December 2006

\begin{abstract}
The local structures of Ti doped $\mathrm{NaAlH}_{4}$ were investigated with extended X-ray absorption fine structure (EXAFS) and X-ray absorption near edge structure (XANES) using $\mathrm{Ti}(\mathrm{OBu})_{4}$ and $\mathrm{TiCl}_{3}$ precursors. The local structures were linked to literature data on hydrogen desorption and absorption kinetics. In the $\mathrm{Ti}(\mathrm{OBu})_{4}$ doped $\mathrm{NaAlH}_{4}$, butoxide or decomposition products thereof $(\mathrm{C}, \mathrm{O}$ atoms $)$ was bonded to Ti after ball-milling, inhibiting the performance of the Ti catalyst. Upon heating, the $\mathrm{C}$ and $\mathrm{O}$ atoms were removed and $\mathrm{Ti}-\mathrm{Al}$ species were formed. The thermodynamical most stable specie, $\mathrm{TiAl}_{3}$, was not formed at $T<300{ }^{\circ} \mathrm{C}$, contrarily to $\mathrm{TiCl}_{3}$ doped $\mathrm{NaAlH}_{4}$. Probably the initially present butoxide group gave rise to inhibition of its formation. Besides that, the butoxide or decompostion products thereof $(\mathrm{C}, \mathrm{O}$ atoms $)$ are also suspected to interfere with the hydrogen uptake of a desorbed $\mathrm{NaAlH}_{4}$.
\end{abstract}

(C) 2006 Elsevier B.V. All rights reserved.

Keywords: Metal hydrides; EXAFS; XANES; Sodium alanate; Hydrogen storage

\section{Introduction}

Since the innovative work of Bogdanovic and Schwickardi from 1997 [1], hydrogen storage using Ti doped sodium alanate $\left(\mathrm{NaAlH}_{4}\right)$ has been subject of much research. This is mainly because sodium alanate displays suitable thermodynamic properties enabling reversible storage of hydrogen at low to medium temperatures suitable for mobile applications. The hydrogen is desorbed in two steps (Eqs. (1) and (2)) with respective equilibrium temperatures of 30 and $110^{\circ} \mathrm{C}$ at 1 bar hydrogen pressure, and delivers a total of $5.6 \mathrm{wt} \%$ hydrogen storage capacity.

$\mathrm{NaAlH}_{4} \leftrightarrow \frac{1}{3} \mathrm{Na}_{3} \mathrm{AlH}_{6}+\frac{2}{3} \mathrm{Al}+\mathrm{H}_{2}$

$\mathrm{Na}_{3} \mathrm{AlH}_{6} \leftrightarrow \frac{1}{3} \mathrm{NaH}+\mathrm{Al}+\frac{1}{5} \mathrm{H}_{2}$

The main difficulty to overcome for applying $\mathrm{NaAlH}_{4}$ as a hydrogen storage material are the slow kinetics for hydrogen

\footnotetext{
* Corresponding author. Tel.: +31 302536778; fax: +31 302511027.

E-mail address: j.h.bitter@chem.uu.nl (J.H. Bitter).
}

desorption and absorption. These unfavorable desorption and absorption rates can be improved by reducing the particle size of the $\mathrm{NaAlH}_{4}$ to the nanometer range [2], or by adding a catalyst, for example $\mathrm{TiCl}_{3}$ or Ti-butoxide, to the alanate $[1,3,5]$. Upon doping, the $\mathrm{TiCl}_{3}$ precursor reacts to $\mathrm{NaAlH}_{4}$ forming $\mathrm{NaCl}$, $\mathrm{Al}$, and a reduced Ti entity as shown in reaction (3) [5]. When $\mathrm{Ti}(\mathrm{OBu})_{4}$ is used, the $\mathrm{Ti}$ is supposed to be reduced via reaction (4) [5].

$$
\begin{aligned}
& \mathrm{TiCl}_{3}+3 \mathrm{NaAlH}_{4} \rightarrow \text { “Ti” }+3 \mathrm{Al}+3 \mathrm{NaCl}+6 \mathrm{H}_{2} \\
& \mathrm{Ti}(\mathrm{OBu})_{4}+\mathrm{NaAlH}_{4} \rightarrow \text { "Ti”" }+\mathrm{NaAl}(\mathrm{OBu})_{4}+2 \mathrm{H}_{2}
\end{aligned}
$$

Several experimental studies reported that the $\mathrm{Ti}$ is finely dispersed, and is present as amorphous nano-particles in the $\mathrm{NaAlH}_{4}$ or Al [6-9]. Therefore, characterization of the Ti on atomic scale is necessary, and suitable techniques are extended $\mathrm{X}$-ray absorption fine structure (EXAFS) and X-ray absorption near edge structure (XANES).

It has been reported that the precursor has an influence on the initial hydrogen desorption and absorption properties, that is $\mathrm{TiCl}_{3}$ doped $\mathrm{NaAlH}_{4}$ display faster hydrogen desorption 
Table 1

Input parameters to create $\mathrm{FEFF}$ calculated $\mathrm{Ti}-\mathrm{Al}, \mathrm{Ti}-\mathrm{Ti}, \mathrm{Ti}-\mathrm{O}$ and $\mathrm{Ti}-\mathrm{C}$ references

\begin{tabular}{|c|c|c|c|c|c|c|}
\hline & reference compound & $S_{0}^{2}$ & $\sigma^{2}\left(10^{3} \AA^{-2}\right)$ & $V_{\mathrm{r}}(\mathrm{eV})$ & $V_{\mathrm{i}}(\mathrm{eV})$ & Potential \\
\hline $\mathrm{Ti}-\mathrm{Al}$ & $\mathrm{TiAl}_{3}$ & 0.72 & 1.50 & 11.3 & 1.0 & Hedin-Lunqvist \\
\hline $\mathrm{Ti}-\mathrm{Ti}$ & $h c p$ Ti foil & 0.60 & 0.00 & 8.6 & 1.0 & Hedin-Lunqvist \\
\hline $\mathrm{Ti}-\mathrm{O}$ & $\mathrm{TiO}_{2}$ rutile & 0.59 & 4.05 & 13.57 & 1.0 & Hedin-Lunqvist \\
\hline $\mathrm{Ti}-\mathrm{C}$ & - & 1.00 & 0.00 & 0 & 1.0 & Hedin-Lunqvist \\
\hline
\end{tabular}

kinetics and also show enhanced hydrogen absorption rates compared to $\mathrm{Ti}(\mathrm{OBu})_{4}$ doped $\mathrm{NaAlH}_{4}[4,10,11]$. Therefore, the proposed Ti entity after ball-milling $\mathrm{TiCl}_{3}$ or $\mathrm{Ti}(\mathrm{OBu})_{4}$ might not possess the same structure, and could be the origin of the difference in the initial kinetics. The atomic structure of $\mathrm{Ti}$ in $\mathrm{NaAlH}_{4}$ has been investigated for $\mathrm{TiCl}_{3}$ [6-9]. However the atomic structure has not been investigated for $\mathrm{Ti}(\mathrm{OBu})_{4}$, and is presented here. The structures are investigated after ball-milling, in situ during hydrogen desorption of $\mathrm{NaAlH}_{4}$, and will be compared to structural data obtained for $\mathrm{TiCl}_{3}$ doped $\mathrm{NaAlH}_{4}$.

\section{Experimental}

All sample preparations were performed under a nitrogen or argon atmosphere in a glovebox equipped with a circulation purifier. Commercially available $\mathrm{NaAlH}_{4}$ (tech. 90\% Sigma Aldrich) was purified and ball-milled with $10 \mathrm{~mol} \% \mathrm{TiCl}_{3}$ and $12 \mathrm{~mol} \% \mathrm{Ti}(\mathrm{OBu})_{4}$ as described before [4]. These samples are referred to as $\mathrm{TiCl}_{3} / \mathrm{NaAlH}_{4}$ and $\mathrm{Ti}(\mathrm{OBu})_{4} / \mathrm{NaAlH}_{4}$. One part of the $\mathrm{TiCl}_{3} / \mathrm{NaAlH}_{4}$ was heated in $\mathrm{Ar}$ to $225^{\circ} \mathrm{C}$ with a ramp of $5^{\circ} \mathrm{C} / \mathrm{min}$ until no detectable hydrogen desorption was recorded by volumetric analysis $\left(\mathrm{TiCl}_{3} / \mathrm{NaAlH}_{4}-225\right)$. The $\mathrm{Ti}(\mathrm{OBu})_{4} / \mathrm{NaAlH}_{4}$ was desorbed in situ to $90^{\circ} \mathrm{C}$, kept isothermal for $30 \mathrm{~min}$, and cooled down $\left(\mathrm{Ti}(\mathrm{OBu})_{4} / \mathrm{NaAlH}_{4}-90\right)$. Next, the sample was desorbed at $150{ }^{\circ} \mathrm{C}$ isothermal for $12 \mathrm{~h}\left(\mathrm{Ti}(\mathrm{OBu})_{4} / \mathrm{NaAlH}_{4}-150\right)$. After that, the temperature was increased to $300^{\circ} \mathrm{C}$ and kept isothermal for 30 $\min \left(\mathrm{Ti}(\mathrm{OBu})_{4} / \mathrm{NaAlH}_{4}-300\right)$.

$\mathrm{X}$-ray absorption spectroscopy was performed on the Ti K-edge at station E4 of the DESY synchrotron (Hamburg, Germany), using a Si (1 111 ) double crystal monochromator that was detuned to $80 \%$ to suppress higher harmonics. All measurements were performed at $77 \mathrm{~K}$ in flowing $\mathrm{He}$ to exclude thermal decomposition of the sample. The samples $\left(11 \mathrm{mg}\right.$ of Ti-doped $\left.\mathrm{NaAlH}_{4}\right)$ were homogeneously diluted with $50 \mathrm{mg} \mathrm{BN}$, pressed in a pellet, mounted to the cell and transferred to the beam-line in a closed cell under inert atmosphere.

Extraction of the EXAFS data was performed as described elsewhere [12]. The Ti-Al backscattering amplitude and phase shift were calculated using the FEFF 8.2 code [13] and calibrated using an experimental measured spectrum at $77 \mathrm{~K}$ so that $E_{0}$ and $\sigma^{2}$ of the references were zero. The FEFF input parameters, and used references are listed in Table 1. Experimental data were fitted in $k^{2}$ using the difference file technique in R-space from $3<k<10$ or $3<k<12\left(\AA^{-1}\right)$ depending on the quality of the data. The quality of the fit was checked by applying $k^{1}, k^{2}$ and $k^{3}$ weightings.

XANES was recorded from 4950 to $5050 \mathrm{eV}$ with a stepsize of $0.3 \mathrm{eV}$. The position of the edge was set at the maximum of the first derivative (inflection point) of the absorption edge. Spectra were normalized to $5020 \mathrm{eV}$.

\section{Results}

The magnitude of the uncorrected Fourier Transform (FT) of $\mathrm{Ti}(\mathrm{OBu})_{4} / \mathrm{NaAlH}_{4}$ and $\mathrm{TiCl}_{3} / \mathrm{NaAlH}_{4}$ treated at various temperatures are shown in Fig. 1. It is observed that the FT changed significantly upon changing temperature and/or precursor. The changes were quantified in the fits of the different samples. The $k^{2}$ variances of the fits (Table 2) are low, indicating that the fits were of a comparable good quality. The fit parameters of $\mathrm{Ti}(\mathrm{OBu})_{4} / \mathrm{NaAlH}_{4}$ are listed in Table 2. It was observed that 4.5 oxygen atoms surrounded $\mathrm{Ti}$ in its closest shell at $1.99 \AA$, which is a typical distance for Ti-oxides [14]. The next shell contained 3.4 Ti-C bonds at $2.49 \AA$. This distance is relatively long for a Ti-C distance, which is typically at $2.1-2.2 \AA$ [15]. However, Ti-C distances of $\sim 2.4 \AA$ have been reported before [15]. No atoms were observed in higher shells.

After heating $\mathrm{Ti}(\mathrm{OBu})_{4} / \mathrm{NaAlH}_{4}$ to $90^{\circ} \mathrm{C}$, the distances of the first two shells altered only slightly. In contrast, the coordination number decreased in both samples from 4.5 to 1.9 (Ti-O), and from 3.4 to 1.9 (Ti-C). Besides that, the third shell displayed an $\mathrm{Al}$ atom at $2.82 \AA$, which was at a typical distance for Ti-Al bonds in Ti doped $\mathrm{NaAlH}_{4}$ systems [6-9]. After heating the sample to $150^{\circ} \mathrm{C}$, the nearest shells did not contain $\mathrm{O}$ or $\mathrm{C}$ atoms (Table $\left.2 \mathrm{Ti}(\mathrm{OBu})_{4} / \mathrm{NaAlH}_{4}-150\right)$. The fit parameters show that two $\mathrm{Al}$ atoms surrounded the $\mathrm{Ti}$ at $2.76,2.92 \AA$,
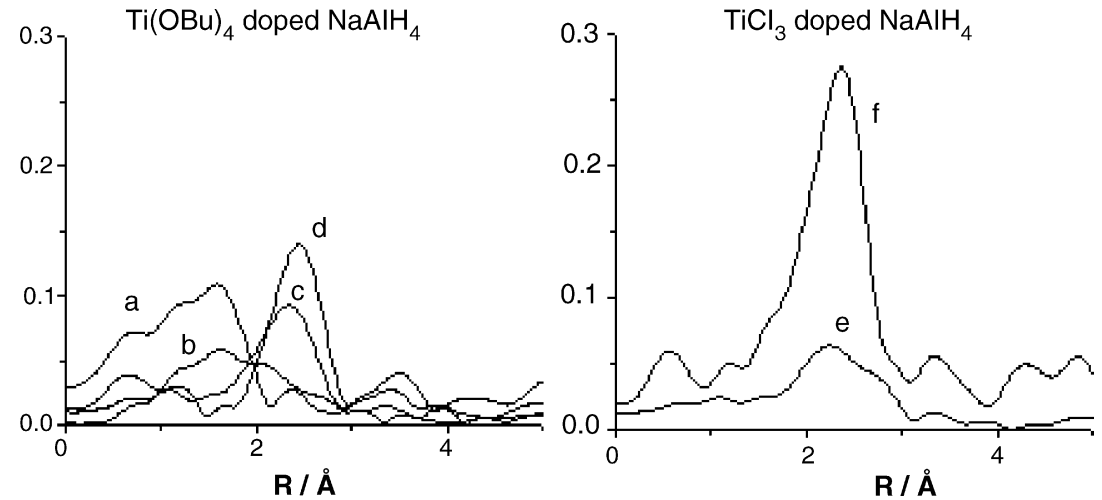

Fig. 1. Magnitude of Fourier transformed $\chi(k)$ : (a) $\mathrm{Ti}(\mathrm{OBu})_{4} / \mathrm{NaAlH}_{4}$, (b) $\mathrm{Ti}(\mathrm{OBu})_{4} / \mathrm{NaAlH}_{4}-90$, (c) $\mathrm{Ti}(\mathrm{OBu})_{4} / \mathrm{NaAlH}_{4}-150,(\mathrm{~d}) \mathrm{Ti}(\mathrm{OBu})_{4} / \mathrm{NaAlH} 4-300,($ e) $\mathrm{TiCl}_{3} / \mathrm{NaAlH}_{4}$, (f) $\mathrm{TiCl}_{3} / \mathrm{NaAlH}_{4}-225$. $\left(k^{1} ; \Delta k ; 3-12 \AA^{-1}\right)$. 
Table 2

EXAFS fits of $\mathrm{Ti}(\mathrm{OBu})_{4}$ doped $\mathrm{NaAlH}_{4}$ after ball-milling, and after desorption at $90^{\circ} \mathrm{C}, 150^{\circ} \mathrm{C}$

\begin{tabular}{|c|c|c|c|c|c|c|c|c|c|}
\hline \multirow[t]{2}{*}{ Name } & \multirow[t]{2}{*}{ Fit range $(\AA)$} & \multirow[t]{2}{*}{ Shell } & \multirow[t]{2}{*}{ Atom } & \multirow[t]{2}{*}{$N$} & \multirow[t]{2}{*}{$\Delta \sigma^{2}\left(10^{3} \AA^{-2}\right)$} & \multirow[t]{2}{*}{$R(\AA)$} & \multirow[t]{2}{*}{$E_{0}(\mathrm{eV})$} & \multicolumn{2}{|c|}{$k^{2}$-variance } \\
\hline & & & & & & & & $\mathrm{Im}$. & Abs. \\
\hline \multirow{2}{*}{$\mathrm{Ti}(\mathrm{OBu})_{4} / \mathrm{NaAlH} 4$} & \multirow[t]{2}{*}{$1.1-2.1$} & 1 & Ti-O & 4.5 & 8.60 & 1.99 & 3.09 & \multirow[t]{2}{*}{0.24} & \multirow[t]{2}{*}{0.17} \\
\hline & & 2 & $\mathrm{Ti}-\mathrm{C}$ & 3.4 & 0.88 & 2.48 & -0.60 & & \\
\hline \multirow[t]{3}{*}{$\mathrm{Ti}(\mathrm{OBu})_{4} / \mathrm{NaAlH}_{4}-90$} & \multirow[t]{3}{*}{$1.0-2.8$} & 1 & Ti-O & 1.9 & 1.78 & 1.91 & 2.40 & \multirow[t]{3}{*}{0.40} & \multirow[t]{3}{*}{1.02} \\
\hline & & 2 & Ti-C & 1.9 & 0.57 & 2.52 & -7.00 & & \\
\hline & & 3 & $\mathrm{Ti}-\mathrm{Al}$ & 1.5 & 3.22 & 2.83 & -1.05 & & \\
\hline \multirow[t]{3}{*}{$\mathrm{Ti}(\mathrm{OBu})_{4} / \mathrm{NaAlH}_{4}-150$} & \multirow[t]{3}{*}{$1.8-3.6$} & 1 & $\mathrm{Ti}-\mathrm{Al}$ & 3.3 & 0.51 & 2.76 & -1.32 & \multirow[t]{3}{*}{0.07} & \multirow[t]{3}{*}{0.10} \\
\hline & & 2 & $\mathrm{Ti}-\mathrm{Al}$ & 2.0 & 0.50 & 2.92 & 0.57 & & \\
\hline & & 3 & Ti-Ti & 1.3 & 0.83 & 3.39 & 4.06 & & \\
\hline \multirow[t]{3}{*}{$\mathrm{Ti}(\mathrm{OBu})_{4} / \mathrm{NaAlH}_{4}-300$} & \multirow[t]{3}{*}{$1.9-3.3$} & 1 & $\mathrm{Ti}-\mathrm{Al}$ & 6.7 & 0.60 & 2.82 & -1.65 & \multirow[t]{3}{*}{0.46} & \multirow[t]{3}{*}{0.25} \\
\hline & & 2 & $\mathrm{Ti}-\mathrm{Al}$ & 3.0 & 0.50 & 3.00 & 4.91 & & \\
\hline & & 3 & Ti-Ti & 2.0 & 3.60 & 3.39 & 8.83 & & \\
\hline \multirow[t]{3}{*}{$\mathrm{TiCl}_{3} / \mathrm{NaAlH}_{4}$} & \multirow[t]{3}{*}{$1.2-3.5$} & 1 & $\mathrm{Ti}-\mathrm{Al}$ & 2.3 & 0.04 & 2.71 & -0.96 & \multirow[t]{3}{*}{0.63} & \multirow[t]{3}{*}{0.40} \\
\hline & & 2 & $\mathrm{Ti}-\mathrm{Al}$ & 2.5 & 0.18 & 2.89 & 0.96 & & \\
\hline & & 3 & Ti-Ti & 1.9 & 0.81 & 3.52 & 1.93 & & \\
\hline \multirow[t]{3}{*}{$\mathrm{TiCl}_{3} / \mathrm{NaAlH}_{4}-225$} & \multirow[t]{3}{*}{$1.2-3.5$} & 1 & $\mathrm{Ti}-\mathrm{Al}$ & 4.6 & 0.10 & 2.73 & 1.53 & \multirow[t]{3}{*}{0.36} & \multirow[t]{3}{*}{0.23} \\
\hline & & 2 & $\mathrm{Ti}-\mathrm{Al}$ & 7.8 & 0.82 & 2.84 & 4.97 & & \\
\hline & & 3 & Ti-Ti & 3.8 & 6.36 & 3.90 & 4.31 & & \\
\hline
\end{tabular}

which are at typical distances for $\mathrm{TiAl}_{x}$ alloys $[6-9,16]$. Further heating increased the $\mathrm{Ti}-\mathrm{Al}$ bond distances slightly, however the coordination number of $\mathrm{Ti}-\mathrm{Al}$ increased significantly from 3.3 to 6.7 , and 2.0 to $3.0 \mathrm{Al}$ atoms in the nearest shells.

The local structure for $\mathrm{TiCl}_{3} / \mathrm{NaAlH}_{4}$ is listed in Table 2, and it is observed that $\mathrm{Al}$ surrounded the Ti. A detailed description of this structure can be found in an upcoming article [9]. After heating to $225^{\circ} \mathrm{C}\left(\mathrm{TiCl}_{3} / \mathrm{NaAlH}_{4}-225\right)$, the local structure was similar to the local structure of $\mathrm{TiAl}_{3}$, that is $4 \mathrm{Al}$ atoms at $2.73 \AA$, $8 \mathrm{Al}$ atoms at $2.84 \AA$, and $4 \mathrm{Ti}$ atoms at $3.90 \AA$.

The XANES of several samples are shown in Fig. 2. The edge positions of all measured samples are listed in Table 3. The first feature in the Ti edge for Ti-oxides, is a pre-edge feature [17] and the edge position was determined at the inflection point of the second rising edge for the samples that contained oxygen, that is $\mathrm{Ti}(\mathrm{OBu})_{4} / \mathrm{NaAlH}_{4}$ and $\mathrm{TiO}_{2}$. For the samples

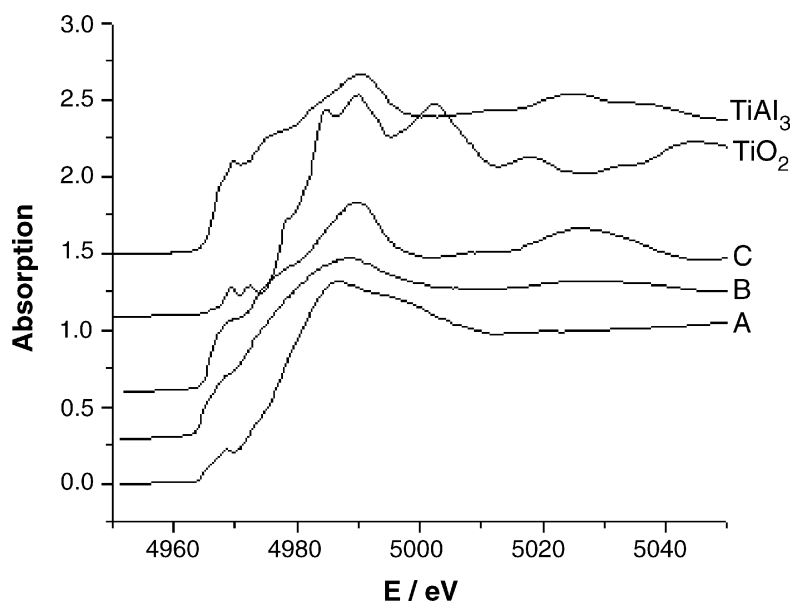

Fig. 2. XANES of (A) $\mathrm{Ti}(\mathrm{OBu})_{4} / \mathrm{NaAlH}_{4}$, (B) $\mathrm{Ti}(\mathrm{OBu})_{4} / \mathrm{NaAlH}_{4}-150$, (C) $\mathrm{TiCl}_{3} / \mathrm{NaAlH}_{4}-225$, and references $\mathrm{TiO}_{2}$ and $\mathrm{TiAl}_{3}$.
Table 3

Positions of Ti-edges in SAH-start, SAH-125, SAH-225, SAH-475 and $\mathrm{TiAl}_{3}$

\begin{tabular}{lc}
\hline & Edge position $(\mathrm{eV})$ \\
\hline $\mathrm{TiCl}_{3} / \mathrm{NaAlH}_{4}$ & 4965.7 \\
$\mathrm{TiCl}_{3} / \mathrm{NaAlH}_{4}-225$ & 4966.1 \\
$\mathrm{Ti}(\mathrm{OBu})_{4} / \mathrm{NaAlH}_{4}$ & 4972.3 \\
$\mathrm{Ti}(\mathrm{OBu})_{4} / \mathrm{NaAlH}_{4}-90$ & - \\
$\mathrm{Ti}(\mathrm{OBu})_{4} / \mathrm{NaAlH}_{4}-150$ & 4967.0 \\
$\mathrm{Ti}(\mathrm{OBu})_{4} / \mathrm{NaAlH}_{4}-300$ & 4967.0 \\
$\mathrm{TiO}_{2}$ & 4976.5 \\
$\mathrm{TiAl}_{3}$ & 4966.7 \\
$\mathrm{Ti}$ foil & 4965.5 \\
\hline
\end{tabular}

that did not contain oxygen, the first rising edge was taken as the absorption edge. No edge energy has been determined for $\mathrm{Ti}(\mathrm{OBu})_{4} / \mathrm{NaAlH}_{4}-90$, as EXAFS fit indicated that local structure involved both oxygen and aluminum atoms, and the absorption edge consists probably of a combination of two oxidation states. It was also observed that the resonances of $\mathrm{Ti}(\mathrm{OBu})_{4} / \mathrm{NaAlH}_{4}$ and $\mathrm{Ti}(\mathrm{OBu})_{4} / \mathrm{NaAlH}_{4}-150$ were less pronounced than the resonances of crystalline references $\mathrm{TiAl}_{3}$ and $\mathrm{TiO}_{2}$ (Fig. 2).

\section{Discussion}

The position of the $\mathrm{Ti}$ absorption edge energy represents the oxidation state of $\mathrm{Ti}$ in Ti-butoxide doped $\mathrm{NaAlH}_{4}$. Table 3 shows that the position of the edge energy was significantly higher for $\mathrm{Ti}(\mathrm{OBu})_{4} / \mathrm{NaAlH}_{4}$ than the position of the edge in Ti-metal. The shift in edge energy is linearly dependant of the oxidation state of $\mathrm{Ti}(\bigcirc$ symbols in Fig. 3) [6]. Note that the edge shift of $\mathrm{TiO}_{2}$ differs $3 \mathrm{eV}$ with $\mathrm{TiO}_{2}$ obtained from literature, probably due to differences in determining the edge energy. Assuming a linear relationship between oxidation state and edge 


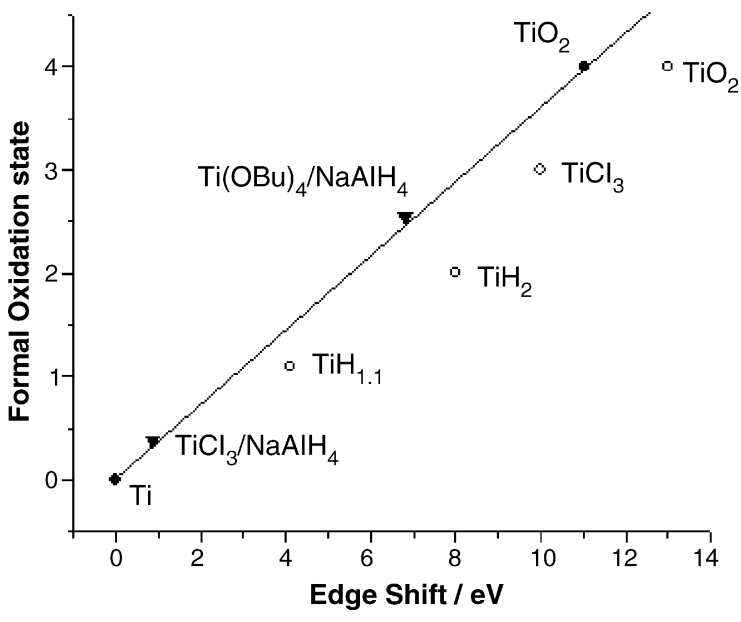

Fig. 3. Shift in Ti K-edge, measured references, used to calibrate samples with unknown valency $(\boldsymbol{\nabla}), \bigcirc$ Ti standards taken from [6].

shift of our recorded Ti-metal and $\mathrm{TiO}_{2}$ (Fig. 3), it is calculated that the formal valency of Ti was $+2.5 \mathrm{in} \mathrm{Ti}(\mathrm{OBu})_{4} / \mathrm{NaAlH}_{4}$ after ball-milling. These findings are in contradiction with the doping reaction between $\mathrm{Ti}(\mathrm{OBu})_{4}$ and $\mathrm{NaAlH}_{4}$ reaction (4), in which the $\mathrm{Ti}$ is claimed to be reduced to $\mathrm{Ti}^{0}$. Contrarily, when doping with $\mathrm{TiCl}_{3}$ the oxidation state was $+0.3\left(\mathrm{TiCl}_{3} / \mathrm{NaAlH}_{4}\right)$, and indicated that the $\mathrm{Ti}$ was reduced to a low oxidation state in the doping process (Fig. 3). It was also observed that the XANES resonances of $\mathrm{Ti}(\mathrm{OBu})_{4}$ doped $\mathrm{NaAlH}_{4}$ were damped compared to crystalline materials such as $\mathrm{TiAl}_{3}$ and $\mathrm{TiO}_{2}$ (Fig. 2). Similar damped resonances were reported and explained by Graetz et al. by presence of surface nano-entities [6]. Probably, in the case of $\mathrm{Ti}(\mathrm{OBu})_{4} / \mathrm{NaAlH}_{4}$ the Ti is highly dispersed on the $\mathrm{NaAlH}_{4}$.

To further investigate the structures of these highly dispersed Ti-particles, the local structures were determined with EXAFS. The EXAFS fit parameters in Table 2 revealed that Ti was surrounded by oxygen and carbon atoms after ball-milling $\mathrm{Ti}(\mathrm{OBu})_{4}$ with $\mathrm{NaAlH}_{4}$. The carbon and oxygen atoms originated from the decomposition of the butoxide group of the Ti-precursor, thus most probably the $\mathrm{Ti}$ was not in the close vicinity of the $\mathrm{NaAlH}_{4}$ in this stage of the experiment. Upon heating to $90^{\circ} \mathrm{C}$, the coordination number of the Ti-O and Ti-C shells decreased from 4.5 to 1.9 (Ti-O), and 3.4 to 1.9 (Ti-C). This indicates that the $\mathrm{C}$ and $\mathrm{O}$ atoms of the Ti were removed for approximately $50 \%$ during this temperature treatment. At the same time Ti-Al scattering at $2.82 \AA$ appeared from the fit (Table 2). This indicates that the heat treatment partly broke the oxygen and carbon bonds, and $\mathrm{Ti}$ reacted with the formed $\mathrm{Al}$ metal (as $\mathrm{NaAlH}_{4}$ decomposed to $\mathrm{NaH}$ and $\mathrm{Al}$ metal). This process prolonged when the sample was heated to $150^{\circ} \mathrm{C}$. Namely, in $\mathrm{Ti}(\mathrm{OBu})_{4} / \mathrm{NaAlH}_{4}-150$, no Ti-O or Ti-C bonds were detected in the closest coordination spheres (Table 2), and the Ti was surrounded by $\mathrm{Al}$ at 2.76 and $2.92 \AA$. The coordination number of $\mathrm{Al}$ was low $(3.3+2.0=5.3)$, since a crystalline $\mathrm{TiAl}_{3}$ alloy has $4+8=12 \mathrm{Al}$ neighbors. Presumably, the Ti is present as Ti-Al nano entities as was also inferred from XANES. As a result, the $\mathrm{Ti}-\mathrm{O}-\mathrm{C}$ that was present in the pristine sample was probably converted to an $\mathrm{Na}-\mathrm{Al}-\mathrm{O}-\mathrm{C}-\mathrm{H}$ phase. The coordination number of $\mathrm{Al}$ increased further when the sample was heated to $300{ }^{\circ} \mathrm{C}$
$\left(\mathrm{Ti}(\mathrm{OBu})_{4} / \mathrm{NaAlH}_{4}-300\right)$, but the local structure was dissimilar to $\mathrm{TiAl}_{3}$.

In the EXAFS fits of $\mathrm{TiCl}_{3}$ milled $\mathrm{NaAlH}_{4}$, the chloride precursor ion did not appear in the fits (Table 2), and only Ti-Al distances were observed in the first two shells. This illustrates that $\mathrm{Ti}$ in $\mathrm{TiCl}_{3}$ was more easily reduced than $\mathrm{Ti}$ in $\mathrm{Ti}(\mathrm{OBu})_{4}$. When $\mathrm{TiCl}_{3} / \mathrm{NaAlH}_{4}$ was heated to $225^{\circ} \mathrm{C}\left(\mathrm{TiCl}_{3} / \mathrm{NaAlH}_{4}\right.$ 225) the local structure was identical to the local structure of $\mathrm{TiAl}_{3}$, and contained $4+8=12 \mathrm{Al}$ atoms. This indicates that thermodynamical lowest state $\left(\mathrm{TiAl}_{3}\right)$ had been reached. After heating the $\mathrm{Ti}$ in $\mathrm{Ti}(\mathrm{OBu})_{4}$ doped $\mathrm{NaAlH}_{4}$, the Ti enriched with $\mathrm{Al}$ atoms. However, its first coordination sphere contained $3+6.7=9.7 \mathrm{Al}$ atoms after the final temperature treatment to $300{ }^{\circ} \mathrm{C}\left(\mathrm{Ti}(\mathrm{OBu})_{4} / \mathrm{NaAlH}_{4}-300\right)$. Thus, the $\mathrm{Ti}$ was not fully surrounded by $\mathrm{Al}$ atoms in this sample, and did not reach the thermodynamical lowest state ( $\mathrm{TiAl}_{3}$ alloy). Apparently, the thermodynamical lowest state was reached slower with $\mathrm{Ti}(\mathrm{OBu})_{4}$ precursor than using $\mathrm{TiCl}_{3}$.

Several reports indicate that the hydrogen desorption rates are faster for the $\mathrm{TiCl}_{3}$ dopant than for $\mathrm{Ti}(\mathrm{OBu})_{4}$, and this has also been confirmed for our investigated samples (not shown) $[4,10,11]$. It was observed that the oxidation state of the Ti was +2.5 in $\mathrm{Ti}(\mathrm{OBu})_{4} / \mathrm{NaAlH}_{4}$ and +0.3 in $\mathrm{TiCl}_{3} / \mathrm{NaAlH}_{4}$ (Fig. 3). It might be that the oxidation state of $\mathrm{Ti}$ is of crucial importance for its catalytic performance. Another, related, explanation is that the butoxide group occupies space around $\mathrm{Ti}$, and shields the Ti from $\mathrm{NaAlH}_{4}$ leading to a lesser active Ti-catalyst.

Besides improved desorption rates, hydrogen absorption rates and capacities are also better using $\mathrm{TiCl}_{3}$ than Ti-butoxide [4]. The coordination number of $\mathrm{Al}$ around $\mathrm{Ti}$ is low in $\mathrm{Ti}(\mathrm{OBu})_{4} / \mathrm{NaAlH}_{4}-150$, which is a sign that $\mathrm{Ti}$ particles were small and/or at the surface. In contrast, the coordination number for $\mathrm{TiCl}_{3}$ doped $\mathrm{NaAlH}_{4}$ is higher, but still displays better absorption rates and capacities [4,9]. As Ti-Al surface or nano entities are considered as the active species [6-9], this kinetic difference cannot be explained on basis of EXAFS/XANES results. As concluded before, the butoxide groups were removed from the $\mathrm{Ti}$, but an in situ gas phase IR experiment did not indicate presence of hydrocarbons upon heating $\mathrm{Ti}(\mathrm{OBu})_{4} / \mathrm{NaAlH}_{4}$ to $450{ }^{\circ} \mathrm{C}$. Thus, the butoxide must have reacted with $\mathrm{NaAlH}_{4}, \mathrm{NaH}$ or $\mathrm{Al}$. The ratio of carbon to aluminum is high $(\mathrm{C} / \mathrm{Al}$ ratio $=1.9)$, and interferes most likely with $\mathrm{H}_{2}$ absorption process, that is Ti-catalyst is blocked by remaining $\mathrm{C}$ and $\mathrm{O}$ atoms.

\section{Conclusions}

Doping $\mathrm{Ti}(\mathrm{OBu})_{4}$ and $\mathrm{TiCl}_{3}$ under identical conditions yields different Ti species. For $\mathrm{TiCl}_{3}$, Ti was reduced to $\mathrm{Ti}^{0.3}$, whereas for $\mathrm{Ti}(\mathrm{OBu})_{4}$ the $\mathrm{Ti}$ oxidation state was +2.5 , and the butoxide groups and/or $\mathrm{C}$ and $\mathrm{O}$ atoms were detected around $\mathrm{Ti}$. The presence of carbon and oxygen inhibited the Ti catalyst for hydrogen desorption. The butoxide groups were removed in between 90 and $150{ }^{\circ} \mathrm{C}$, and delayed the formation of the thermodynamical most stable state $\left(\mathrm{TiAl}_{3}\right.$ alloy) compared to when a more easily reducible Ti-agent, $\mathrm{TiCl}_{3}$, was used. The presence of carbon and oxygen atoms in the bulk interferes possibly with hydrogen uptake and the activity of the Ti-catalyst. 


\section{Acknowledgements}

This work was financially supported by ACTS, project number 053.61.02, and HASYLAB project number I-05-062 EC. We thank Dr. Konstantin Klementiev from HASYLAB for providing $\mathrm{TiAl}_{3}$. We also thank F. Soulimani from Utrecht University for assistance during the IR-experiment.

\section{References}

[1] B. Bogdanovic, M. Schwickardi, J. Alloys Compd. 253-254 (1997) 1-9.

[2] C.P. Baldé, B.P.C. Hereijgers, J.H. Bitter, K.P. de Jong, Angew. Chem. Int. Ed. 45 (2006) 3501-3503.

[3] C.M. Jensen, R.A. Zidan, N. Mariels, A.G. Hee, C. Hagen, Int. J. Hydrogen Energy 24 (1999) 461.

[4] A.G. Haiduc, H.A. Stil, M.A. Schwarz, P. Paulus, J.J.C. Geerlings, J. Alloys Compd. 393 (2005) 252-263.

[5] J.M. Bellosta von Colbe, B. Bogdanovic, M. Felderhof, A. Pommerin, F. Schüth, J. Alloys Compd. 370 (2004) 104-109.

[6] J. Graetz, J.J. Reilly, J. Johnson, A.Y. Ignatov, T.A. Tyson, Appl. Phys. Lett. 85 (2004) 500-502.
[7] M. Felderhoff, K. Klementiev, W. Grunert, B. Spliethoff, B. Tesche, J.M. Bellosta Von Colbe, B. Bogdanovic, M. Hartel, A. Pommerin, F. Schüth, C. Weidenthaler, Phys. Chem. Chem. Phys. 6 (2004) 4369-4374.

[8] A. Léon, O. Kircher, J. Rothe, M. Fichtner, J. Phys. Chem. B 108 (2004) 16372-16376.

[9] C.P. Baldé, H.A. Stil, A. M.J. van der Eerden, K.P. de Jong, J.H. Bitter, J. Phys. Chem. C, in press.

[10] B. Bogdanovic, R.A. Brand, A. Marjanovic, M. Schwickardi, J. Tölle, J. Alloys Compd. 302 (2000) 36-58.

[11] F. Schüth, B. Bogdanovic, M. Felderhof, Chem. Commun. 37 (2004) 2249-2258.

[12] D.C. Koningsberger, B.L. Mojet, G.E. Van Dorssen, D.E. Ramaker, Top. Catal. 10 (2000) 143-155.

[13] S.I. Zabinsky, J.J. Rehr, A.L. Ankudinov, R.C. Albers, H.J. Eller, Phys. Rev. B: Condens. Matter 52 (1995) 2995.

[14] L. Vegard, Philos. Mag. 32 (1916) 505-518.

[15] E.P. Wasserman, A.D. Westwood, Z. Yu, J.H. Oskam, S.L. Duenas, J. Mol Catal. A: Chem. 172 (2001) 67-80.

[16] P. Norby, A.N. Christensen, Acta Chem. Scand., Series A 40 (1986) $157-159$.

[17] F. Farges, G.E. Brown Jr., J.J. Rehr, Phys. Rev. B: Condens. Matter 56 (1997) 1809-1819. 